\author{
A.T. Assanova ${ }^{1}$, A.E. Imanchiyev ${ }^{2}$ \\ ${ }^{1}$ Institute of Mathematics and Mathematical Modeling SC MES RK, Almaty, Kazakhstan; \\ ${ }^{2}$ K.Zhubanov Aktobe Regional State University, Kazakhstan
}

(E-mail:assanova@math.kz)

\title{
On the unique solvability of a family of multipoint-integral boundary value problems for a third order differential equation
}

\begin{abstract}
A family multipoint-integral boundary value problems for a third order differential equation with variable coefficients is considered. The questions of a existence unique solution of the considered problem and ways of its construction are investigated. The family multipoint-integral boundary value problems for the differential equation of third order with variable coefficients is reduced to a family multipoint-integral boundary value problems for a system of three differential equations by introducing new functions. For solve of resulting family of multipoint-integral boundary value problems is applied a parametrization method. An algorithms of finding the approximate solution to the family multipoint-integral boundary value problems for the system of three differential equations are proposed and their convergence is proved. The conditions of the unique solvability of the family multipoint-integral boundary value problems for the system of three differential equations are obtained in the terms of initial data. The results also formulated relative to the original of the family multipoint-integral boundary value problems for the differential equation of third order with variable coefficients.
\end{abstract}

Keywords: multipoint-integral boundary value problem, third order differential equations, parameter, family of multipoint-integral boundary value problems, system of differential equations, algorithm, unique solvability.

\section{Introduction}

Mathematical modeling of various processes in physics, chemistry, biology, technology, ecology, economics and others are leaded to multipoint-integral boundary value problems for differential equations of higher orders with variable coefficients and parameters [1-8]. The problems of solvability of multipoint-integral boundary value problems remain important for applications because they are directly connected with the theory of splines and interpolations and used in the theory of multi-support beams. Despite the presence of numerous works, general statements of multipoint-integral problems for ordinary differential equations with parameters remain poorly studied up to now. The method of Green functions proves to be the main method for the investigation and solution of family multipoint-integral boundary value problems. This method reflects the specific features of the analyzed boundary value problems. However, the problem of construction of the Green function is quite complicated due to the complex nature of the investigated object and the absence of the required information about its properties.

One of possible ways of overcoming these difficulties is connected with the development of constructive methods aimed at the investigation and solving of family multipoint-integral boundary value problems for higher order differential equations without using the fundamental matrix and the Green function. Thus, in [9], a parametrization method was proposed for the investigation and solving of two-point boundary value problems for ordinary differential equations. Parallel with construction of the coefficient criteria for the unique solvability of the investigated problem, parametrization method enables one to propose algorithms for finding the solution of this problem. In $[10,11]$, the parametrization method was applied to multipoint boundary value problem for ordinary differential equations. A family of multipoint boundary value problems for system of differential equations and multipoint nonlocal problem for system of hyperbolic equations were considered in [12, 13].

In the present paper we study of a questions the existence and uniqueness of solutions to family of multipointintegral boundary value problems for the third-order differential equations and the methods of finding its approximate solutions. For these purposes, we are applied parametrization method [9] for solve of this problem.

We consider the family multipoint-integral boundary value problems for the third-order differential equation

$$
\frac{\partial^{3} z}{\partial t^{3}}=A_{1}(t, x) \frac{\partial^{2} z}{\partial t^{2}}+A_{2}(t, x) \frac{\partial z}{\partial t}+A_{3}(t, x) z+f(t, x), \quad t \in(0, T), \quad x \in[0, \omega]
$$




$$
\begin{gathered}
\sum_{i=0}^{m}\left\{\alpha_{i 1}(x) \frac{\partial^{2} z\left(t_{i}, x\right)}{\partial t^{2}}+\beta_{i 1}(x) \frac{\partial z\left(t_{i}, x\right)}{\partial t}+\gamma_{i 1}(x) z\left(t_{i}, x\right)\right\}+ \\
+\int_{0}^{T}\left\{K_{11}(\tau, x) \frac{\partial^{2} z(\tau, x)}{\partial \tau^{2}}+K_{12}(\tau, x) \frac{\partial z(\tau, x)}{\partial \tau}+K_{13}(\tau, x) z(\tau, x)\right\} d \tau=d_{1}(x), \quad x \in[0, \omega] ; \\
\sum_{i=0}^{m}\left\{\alpha_{i 2}(x) \frac{\partial^{2} z\left(t_{i}, x\right)}{\partial t^{2}}+\beta_{i 2}(x) \frac{\partial z\left(t_{i}, x\right)}{\partial t}+\gamma_{i 2}(x) z\left(t_{i}, x\right)\right\}+ \\
+\int_{0}^{T}\left\{K_{21}(\tau, x) \frac{\partial^{2} z(\tau, x)}{\partial \tau^{2}}+K_{22}(\tau, x) \frac{\partial z(\tau)}{\partial \tau}+K_{23}(\tau, x) z(\tau, x)\right\} d \tau=d_{2}(x) ; \\
+\int_{0}^{T}\left\{K_{31}(\tau, x) \frac{\partial^{2} z(\tau, x}{\partial \tau^{2}}+K_{32}(\tau, x) \frac{\partial z(\tau, x)}{\partial \tau}+K_{33}(\tau, x) z(\tau, x)\right\} d \tau=d_{3}(x) .
\end{gathered}
$$

Here $z(t, x)$ is unknown function, the functions $A_{k}(t, x), f(t, x)$ are continuous on $\Omega=[0, T] \times[0, \omega], k=1,2,3$, $\alpha_{i j}(x), \beta_{i j}(x), \gamma_{i j}(x), d_{j}(x)$ are continuous functions on $[0, \omega]$, the functions $K_{j}(t, x)$ are continuous on $\Omega, \quad i=\overline{0, m}, j=1,2,3,0=t_{0}<t_{1}<t_{2}<\ldots<t_{m-1}<t_{m}=T$.

Let $C(\Omega, R)$ be a space of continuous functions $z: \Omega \rightarrow R$ on $\Omega$ with norm $\|u\|_{0}=\max _{(t, x) \in \Omega}|z(t, x)|$. The function $z(t, x) \in C(\Omega, R)$, that has partial derivatives $\frac{\partial z(t, x)}{\partial t} \in C(\Omega, R), \quad \frac{\partial^{2} z(t, x)}{\partial t^{2}} \in C(\Omega, R)$, $\frac{\partial^{3} z(t, x)}{\partial t^{3}} \in C(\Omega, R)$ is called a solution to family of problems (1)-(4) if it satisfies third-order differential equation (1) for all $(t, x) \in \Omega$ and meets the boundary conditions (2), (3) and (4) for all $x \in[0, \omega]$.

For fixed $x \in[0, \omega]$ problem (1)-(4) is a linear multipoint-integral boundary value problem for the third order ordinary differential equations. Suppose a variable $x$ is changed on $[0, \omega]$; then we obtain a family of multipoint-integral boundary value problems for ordinary differential equations.

We will investigate the existence of a unique solution to the family of multipoint-integral boundary value problems for the third-order differential equation (1)-(4). We use parametrization method for solve of the family problems (1)-(4) and construct of its approximate solutions. An algorithms of finding the approximate solution to the family of multipoint-integral boundary value problems for the system of three differential equations are constructed and their convergence is proved. The conditions of the unique solvability of the family of multipointintegral boundary value problems for the system of three differential equations are established in the terms of initial data. The results also formulated relative to the original of the family multipoint-integral boundary value problems for the differential equation of third order with variable coefficients. The obtained results are applied to a family of multi-point boundary value problems for the third order ordinary differential equation. The efficiency of the proposed approach for solve of the multi-point boundary value problems for the third order differential equations that arise in applications. The results can also be used in the study and solve of a nonlinear multipoint-integral boundary value problems for the third order differential equations. Some types of problems (1)-(4) were studied in [1-8]. For fixed $x$ and $K_{i j}(t, x)=0, i=\overline{1,3}, j=\overline{1,3}$, the problem (1)-(4) were considered in [14]. At fixed $x$ the problem (1)-(4) were investigated in [15].

\section{Scheme of the method}

We introduce the following notations

$$
\begin{array}{ll}
A(t, x)=\left(\begin{array}{ccc}
0 & 1 & 0 \\
0 & 0 & 1 \\
A_{3}(t, x) & A_{2}(t, x) & A_{1}(t, x)
\end{array}\right), \quad F(t, x)=\left(\begin{array}{c}
0 \\
0 \\
f(t, x)
\end{array}\right), \quad d(x)=\left(\begin{array}{c}
d_{1}(x) \\
d_{2}(x) \\
d_{3}(x)
\end{array}\right) ; \\
M_{i}(x)=\left(\begin{array}{ccc}
\gamma_{i 1}(x) & \beta_{i 1}(x) & \alpha_{i 1}(x) \\
\gamma_{i 2}(x) & \beta_{i 2}(x) & \alpha_{i 2}(x) \\
\gamma_{i 3}(x) & \beta_{i 3}(x) & \alpha_{i 3}(x)
\end{array}\right), & K(t, x)=\left(\begin{array}{ccc}
K_{13}(t, x) & K_{12}(t, x) & K_{11}(t, x) \\
K_{23}(t, x) & K_{22}(t, x) & K_{21}(t, x) \\
K_{33}(t, x) & K_{32}(t, x) & K_{31}(t, x)
\end{array}\right) .
\end{array}
$$


$I$ is identity matrix of dimension 3 .

Problem (1)-(4) can be write in the vector-matrix form

$$
\begin{gathered}
\frac{\partial u}{\partial t}=A(t, x) u+F(t, x) \\
\sum_{i=0}^{m} M_{i}(x) u\left(t_{i}, x\right)+\int_{0}^{T} K(\tau, x) u(\tau, x) d \tau=d(x),
\end{gathered}
$$

where $u(t, x)=\left(u_{1}(t, x), u_{2}(t, x), u_{3}(t, x)\right)^{\prime}, u_{1}(t, x)=z(t, x), u_{2}(t, x)=\frac{\partial z(t, x)}{\partial t}, u_{3}(t, x)=\frac{\partial^{2} z(t, x)}{\partial t^{2}}$.

A continuously differentiable function $u: \Omega \rightarrow R^{3}$ is called a solution of the family multipoint-integral boundary value problems (5), (6) if it satisfies system (5) for all $(t, x) \in \Omega$ and condition (6) for all $x \in[0, \omega]$. By $\mu(x)$, we denote the value of the function $u(t, x)$ for $t=t_{0}$.

We perform the change $u(t, x)=\widetilde{u}(t, x)+\mu(x)$ in the problem (5), (6).

Then problem (5), (6) is reduced to the following equivalent problem with unknown functional parameter $\mu(x)$ :

$$
\begin{gathered}
\frac{\partial \widetilde{u}}{\partial t}=A(t, x) \widetilde{u}+A(t, x) \mu(x)+F(t, x) \\
\widetilde{u}\left(t_{0}, x\right)=0, \quad x \in[0, \omega] \\
\sum_{i=0}^{m} M_{i}(x) \mu(x)+\sum_{i=1}^{m} M_{i}(x) \widetilde{u}\left(t_{i}, x\right)+\int_{0}^{T} K(\tau, x) \widetilde{u}(\tau, x) d \tau+\int_{0}^{T} K(\tau, x) d \tau \mu(x)=d(x), \quad x \in[0, \omega] .
\end{gathered}
$$

A pair $(\widetilde{u}(t, x), \mu(x))$ is called a solution to family of problems with parameter (7)-(9) if the function $\widetilde{u}(t, x)$ is continuous and continuously differentiable by $t$ on $\Omega$, satisfies of the system $(7)$ for all $(t, x) \in \Omega$, initial condition (8) and multipoint-integral condition (8) for all $x \in[0, \omega]$.

Problems (5)-(6) and (7)-(9) are equivalent. If a vector function $u(t, x)$ is a solution to family of multipoint-integral problems $(5),(6)$, then a pair $(\widetilde{u}(t, x), \mu(x))$, where $\widetilde{u}(t, x)=u(t, x)-u\left(t_{0}, x\right), \mu(x)=u\left(t_{0}, x\right)$, be a solution to family of problems with functional parameter $(7)-(9)$. And conversely, if a pair $\left(\widetilde{u}^{*}(t, x), \mu^{*}(x)\right)$ is a solution to family of problems with functional parameter (7)-(9), then a vector function $u^{*}(t, x)=\widetilde{u}^{*}(t, x)+\mu^{*}(x)$ be a solution to original family of multipoint-integral problems (5), (6). At fixed $\mu(x)$ the problem $(7),(8)$ is a family of Cauchy problems for system of three differential equations and the relation (9) is connected a values of function $\widetilde{u}(t, x)$ with unknown parameter $\mu(x)$.

A solution of the family of Cauchy problems (7), (8) is equivalent to a family of Volterra integral equations second kind

$$
\widetilde{u}(t, x)=\int_{0}^{t} A(\tau, x) \widetilde{u}(\tau, x) d \tau+\int_{0}^{t} A(\tau, x) d \tau \mu(x)+\int_{0}^{t} F(\tau, x) d \tau, \quad(t, x) \in \Omega .
$$

Substituting the right-hand side of the integral equation (10) instead of the function $\widetilde{u}(\tau, x)$ at $t=\tau$ and repeating the process $\nu$ th time $(\nu=1,2,3, \ldots)$, we get

$$
\widetilde{u}(t, x)=D_{\nu}(t, x) \mu(x)+G_{\nu}(t, x, \widetilde{u})+\widetilde{F}_{\nu}(t, x), \quad(t, x) \in \Omega,
$$

where

$$
\begin{gathered}
D_{\nu}(t, x)=\int_{0}^{t} A(\tau, x) d \tau+\int_{0}^{t} A(\tau, x) \int_{0}^{\tau} A\left(\tau_{1}, x\right) d \tau_{1} d \tau+\ldots+ \\
+\int_{0}^{t} A(\tau, x) \int_{0}^{\tau} A\left(\tau_{1}, x\right) \ldots \int_{0}^{\tau_{\nu-1}} A\left(\tau_{\nu}, x\right) d \tau_{\nu} d \tau_{\nu-1} \ldots d \tau_{1} d \tau \\
G_{\nu}(t, x, \widetilde{u})=\int_{0}^{t} A(\tau, x) \int_{0}^{\tau} A\left(\tau_{1}, x\right) \ldots \int_{0}^{\tau_{\nu-1}} A\left(\tau_{\nu}, x\right) \widetilde{u}\left(\tau_{\nu}, x\right) d \tau_{\nu} d \tau_{\nu-1} \ldots d \tau_{1} d \tau
\end{gathered}
$$




$$
\begin{gathered}
\widetilde{F}_{\nu}(t, x)=\int_{0}^{t} F(\tau, x) d \tau+\int_{0}^{t} A(\tau, x) \int_{0}^{\tau} F\left(\tau_{1}, x\right) d \tau_{1} d \tau+\ldots+ \\
+\int_{0}^{t} A(\tau, x) \int_{0}^{\tau} A\left(\tau_{1}, x\right) \ldots \int_{0}^{\tau_{\nu-1}} F\left(\tau_{\nu}, x\right) d \tau_{\nu} d \tau_{\nu-1} \ldots d \tau_{1} d \tau .
\end{gathered}
$$

From the representation (11) we determine the values of function $\widetilde{u}(t, x)$ for $t=t_{i}, i=\overline{1, m}, t=\tau$ and substitute them into the appropriate expression (9). Then, we obtain

$$
\begin{gathered}
{\left[M_{0}(x)+\sum_{i=1}^{m} M_{i}(x)\left[I+D_{\nu}\left(t_{i}, x\right)\right]+\int_{0}^{T} K(\tau, x)\left[I+D_{\nu}(\tau, x)\right] d \tau\right] \mu(x)=d(x)-\sum_{i=1}^{m} M_{i}(x) \widetilde{F}_{\nu}\left(t_{i}, x\right)-} \\
\quad-\int_{0}^{T} K(\tau, x) \widetilde{F}_{\nu}(\tau, x) d \tau-\sum_{i=1}^{m} M_{i}(x) G_{\nu}\left(t_{i}, x, \widetilde{u}\right)-\int_{0}^{T} K(\tau, x) G_{\nu}(\tau, x, \widetilde{u}) d \tau .
\end{gathered}
$$

The relation (12) is a linear system of three functional equations with respect to parameter $\mu(x)$.

Introduce the notation $Q_{\nu}(T, x)=M_{0}(x)+\sum_{i=1}^{m} M_{i}(x)\left[I+D_{\nu}\left(t_{i}, x\right)\right]+\int_{0}^{T} K(\tau, x)\left[I+D_{\nu}(\tau, x)\right] d \tau$. If for some $\nu \in \mathbb{N}$ the $(3 \times 3)$ matrix $Q_{\nu}(T, x)$ is invertible for all $x \in[0, \omega]$, then at fixed values $\widetilde{u}$ the functional parameter $\mu(x)$ is uniquely determined from system (12). So, for finding a solution to family of problems (7)-(9) we have a closed system of equations (10) and (12).

\section{Algorithm and main result}

If the function $\widetilde{u}(t, x)$ is known, then parameter $\mu(x)$ can be found from the system of functional equations (12). Conversely, if parameter $\mu(x)$ is known, then function $\widetilde{u}(t, x)$ can be found from the family of Cauchy problem for system of differential equations (7), (8). Since neither $\widetilde{u}(t, x)$ nor $\mu(x)$ are known, we use the iterative method and find the solution of family problems with parameter (7)-(9) in the form of a pair $\left(\widetilde{u}^{*}(t, x), \mu^{*}(x)\right)$ as the limit of a sequence $\left(\widetilde{u}^{(k)}(t, x), \mu^{(k)}(x)\right), k=0,1,2, \ldots$, determined according to the following algorithm:

Step 0. Assume that, for chosen $\nu \in \mathbb{N}$ the matrix $Q_{\nu}(T, x): R^{3} \rightarrow R^{3}$ is invertible for all $x \in[0, \omega]$. We use the initial condition (8). We determine the initial approximation in the parameter $\mu^{(0)}(x)$ from the system of functional equations $Q_{\nu}(T, x) \mu(x)=d(x)-\sum_{i=1}^{m} M_{i}(x) \widetilde{F}_{\nu}\left(t_{i}, x\right)$ for all $x \in[0, \omega]$.

We solve the family of Cauchy problems $(7),(8)$ for $\mu(x)=\mu^{(0)}(x)$ and find of function $\widetilde{u}^{(0)}(t, x)$ for all $(t, x) \in \Omega$.

Step 1. Substituting the obtained function $\widetilde{u}^{(0)}(t, x)$ for $\widetilde{u}(t, x)$, from the system of functional equations (12), we obtain $\mu^{(1)}(x)$ for all $x \in[0, \omega]$. Further, we solve the family of Cauchy problems $(7),(8)$ for $\mu(x)=\mu^{(1)}(x)$ and find of function $\widetilde{u}^{(1)}(t, x)$ for all $(t, x) \in \Omega$.

And so on.

Step $k$. Substituting the obtained function $\widetilde{u}^{(k-1)}(t, x)$ for $\widetilde{u}(t, x)$, from the system of functional equations (12), we get $\mu^{(k)}(x)$ for all $x \in[0, \omega]$. Solving the family of Cauchy problems (7), (8) for $\mu(x)=\mu^{(1)}(x)$, we find $\widetilde{u}^{(k)}(t, x)$ for all $(t, x) \in \Omega, k=0,1,2, \ldots$.

Introduce a notations

$$
\begin{aligned}
& a(x)=\max _{t \in[0, T]}\|A(t, x)\|=\max \left(1, \max _{t \in[0, T]}\left\{\left|A_{1}(t, x)\right|+\left|A_{2}(t, x)\right|+\left|A_{3}(t, x)\right|\right\}\right) ; \\
& \kappa(x)=\max _{t \in[0, T]}\|K(t, x)\|=\max _{t \in[0, T]} \max _{i=1,3}\left\{\left|K_{i 1}(t, x)\right|+\left|K_{i 2}(t, x)\right|+\left|K_{i 3}(t, x)\right|\right\} .
\end{aligned}
$$

The following theorem establishes sufficient conditions for the applicability and convergence of the algorithm proposed above, which also guarantee the unique solvability of problem (5), (6).

Theorem 1. Let for some $\nu \in \mathbb{N}$ the matrix $Q_{\nu}(T, x): R^{3} \rightarrow R^{3}$ is invertible for all $x \in[0, \omega]$ and let the following inequalities be true:

a) $\left\|\left[Q_{\nu}(T, x)\right]^{-1}\right\| \leq \eta_{\nu}(T, x)$, where $\eta_{\nu}(T, x)$ is a positive continuous on $x \in[0, \omega]$ function;

b) $q_{\nu}(T, x)=\eta_{\nu}(T, x) \cdot\left(\sum_{i=1}^{m}\left\|M_{i}(x)\right\|+\kappa(x) T\right) \max _{i=1, m}\left[e^{a(x) t_{i}}-1-\sum_{j=1}^{\nu} \frac{\left[a(x) t_{i}\right]^{j}}{j !}\right] \leq \chi<1$, where $\chi$ is a constant. 
Then family of multipoint-integral boundary value problems (5), (6) has a unique solution.

The proof of theorem 1 is similar of proof theorem 1 .

By using the parametrization method, we split the procedure of determination of unknown functions into two part:

1) determination of the unknown function $\widetilde{u}(t, x)$ from the family of Cauchy problems for system of three partial differential equations (7), (8);

2) determination of the introduced parameter $\mu(x)$ from the system of functional equations (12).

Taking into account the notations and the equivalent transition to problem (5), (6), we have.

Theorem 2. Let for some $\nu \in \mathbb{N}$ the matrix $Q_{\nu}(T, x): R^{3} \rightarrow R^{3}$ is invertible for all $x \in[0, \omega]$ and let the inequalities a), b) of Theorem 1 be true.

Then family of multipoint-integral boundary value problems for the third-order differential equation (1)-(4) has a unique solution.

Example. We consider the family of boundary value problems [8]:

$$
\begin{array}{ccc}
\frac{\partial^{3} z}{\partial t^{3}}=p(t, x) z+f(t, x)+r, & t \in(a, b), \quad x \in[0,1] ; \\
z(a, x)=\alpha, & x \in[0,1] ; \\
\frac{\partial z(a, x)}{\partial t}=\beta_{1}, & x \in[0,1] ; \\
\frac{\partial z(b, x)}{\partial t}=\beta_{2}, & x \in[0,1] .
\end{array}
$$

Assume that the functions $f(t, x)$ and $p(t, x)$ are given, and $p(t, x)=0$ for $t \in[a, c) \cup(d, b], a<c<d<b$, and $x \in[0,1]$, the parameter $r, \alpha, \beta_{1}$, and $\beta_{2}$ are constants.

For this problem

$$
\begin{aligned}
& A(t, x)=\left(\begin{array}{ccc}
0 & 1 & 0 \\
0 & 0 & 1 \\
0 & 0 & p(t, x)
\end{array}\right), \quad F(t, x)=\left(\begin{array}{c}
0 \\
0 \\
f(t, x)+r
\end{array}\right) \\
& M_{0}(x)=\left(\begin{array}{lll}
1 & 0 & 0 \\
0 & 1 & 0 \\
0 & 0 & 0
\end{array}\right), \quad M_{1}(x)=\left(\begin{array}{ccc}
0 & 0 & 0 \\
0 & 0 & 0 \\
0 & 1 & 0
\end{array}\right), \quad K(t, x)=\left(\begin{array}{lll}
0 & 0 & 0 \\
0 & 0 & 0 \\
0 & 0 & 0
\end{array}\right), \quad \tilde{d}(x)=\left(\begin{array}{c}
\alpha \\
\beta_{1} \\
\beta_{2}
\end{array}\right) ; \\
& \widetilde{D}_{\nu}(a, t, x)=\int_{a}^{t} A(\tau, x) d \tau+\int_{a}^{t} A(\tau, x) \int_{a}^{\tau} A\left(\tau_{1}, x\right) d \tau_{1} d \tau+\ldots+ \\
& +\int_{a}^{t} A(\tau, x) \int_{a}^{\tau} A\left(\tau_{1}, x\right) \ldots \int_{a}^{\tau_{\nu-1}} A\left(\tau_{\nu}, x\right) d \tau_{\nu} d \tau_{\nu-1} \ldots d \tau_{1} d \tau, \quad \nu=1,2, \ldots \\
& \delta(x)=\max \left(1, \max _{t \in[a, b]}|p(t, x)|\right) .
\end{aligned}
$$

Theorem 3. Let for some $\nu \in \mathbb{N}$ the $(3 \times 3)$ matrix $Q_{\nu}(a, b, x)=M_{0}(x)+M_{1}(x)\left[I+\widetilde{D}_{\nu}(a, b, x)\right.$ is invertible for all $x \in[0,1]$ and let the following inequalities be true:

a) $\left\|\left[\widetilde{Q}_{\nu}(a, b, x)\right]^{-1}\right\| \leq \widetilde{\eta}_{\nu}(a, b, x)$, where $\widetilde{\eta}_{\nu}(a, b, x)$ is a positive continuous on $[0,1]$ function;

b) $\widetilde{q}_{\nu}(a, b, x)=\widetilde{\eta}_{\nu}(a, b, x) \cdot\left[e^{\delta(x)(b-a)}-1-\sum_{j=1}^{\nu} \frac{[\delta(x)(b-a)]^{j}}{j !}\right] \leq \chi<1$.

Then family of two-point boundary value problems for the third-order differential equation (13)-(16) has a unique solution.

Note that in the repeated integrals of the $\widetilde{D}_{\nu}(a, t, x)$ the element of the matrix $A(t, x)$ is function $p(t, x)$ and it will be calculated on the interval $[c, d] \times[0,1]$.

Let $p(t, x)=1$ for $t \in[c, d] \times[0,1], p(t, x)=0$ for $t \in[a, c) \cup(d, b], x \in[0,1]$. 
Then the matrix $Q_{\nu}(a, b, x)$ independent on $x$. In this case, the conditions of Theorem 3 will be formulated only in the terms of numbers $a, b, c, d$.

We have

Theorem 4. Let the $(3 \times 3)$ matrix $Q_{1}(a, b)=\left(\begin{array}{ccc}1 & b-a & 0 \\ 0 & 1+b-a & 0 \\ 0 & 1 & d-c\end{array}\right)$ is invertible and let the following inequalities be true:

a) $\left\|\left[\widetilde{Q}_{1}(a, b)\right]^{-1}\right\| \leq \max \left(\frac{1}{d-c}, 1\right)+\max \left(b-a, 1, \frac{1}{d-c}\right) \frac{1}{1+b-a} ;$

b) $\widetilde{q}_{\nu}(a, b)=\left[\max \left(\frac{1}{d-c}, 1\right)+\max \left(b-a, 1, \frac{1}{d-c}\right) \frac{1}{1+b-a}\right] \cdot\left[e^{(b-a)}-1-(b-a)\right]<1$.

Then two-point boundary value problem for the third-order differential equation (13)-(16) has a unique solution.

So, the family of multipoint-integral boundary value problems for third order differential equation (1)-(4) is reduced to an equivalent family of multipoint-integral boundary value problems for system of differential equation first order. For solve of the family multipoint-integral boundary value problems for system of differential equations results of articles [10-13] are used. Algorithms of finding solutions to the family of multipoint-integral boundary value problems for differential equations are constructed and their convergence is proved. The conditions of the unique solvability to the family of multipoint-integral boundary value problems for third order differential equations are established.

\section{References}

1 Krall A.M. Differential operators and their adjoints under integral and multiple point boundary conditions / A.M. Krall // Journal of Differential Equations. - 1968. - Vol. 4. - P. 327-336.

2 Brown R.C. Ordinary differential operators under Stiltjes boundary conditions / R.C. Brown, A.M. Krall // Trans. Amer. Math. Soc. - 1974. - Vol. 198. - P. 73-92.

3 Lan C. Boundary value problems for second and third order differential equations / C. Lan // Journal of Differential Equations. - 1975. - Vol. 18. - P. 258-274.

4 Самойленко А.М. Численно-аналитические методы исследования решения краевых задач / А.М. Самойленко, Н.И. Ронто. - Киев: Наук. думка, 1985. - 224 с.

5 Agarwal R.P. Existence-uniqueness and iterative methods for third-order boundary value problems / R.P. Agarwal // Journal of Computational and Applied Mathematics. - 1987. - Vol. 17. - P. 271-289.

6 Кигурадзе И.Т. Краевые задачи для систем обыкновенных дифференциальных уравнений / И.Т. Кигурадзе // Итоги науки и техники. Совр. проблемы математики. Нов. достижения. - 1987. - Т. 30. - С. 3-103.

7 Самойленко А.М. Конструктивные методы исследования периодических и многоточечных краевых задач / А.М. Самойленко, В.Н. Лаптинский, К.К. Кенжебаев // Труды Института математики НАН Украины. - Киев: Ин-т математики НАН Украины, 1999. - Т. 29. - 220 с.

8 Xie S. High order compact finite difference schemes for a system of third order boundary value problem / S. Xie, P. Li, Z. Gao, H. Wang // Applied Mathematics and Computation. - 2012. - Vol. 219. P. 2564-2573.

9 Dzhumabayev D.S. Criteria for the unique solvability of a linear boundary-value problem for an ordinary differential equation / D.S. Dzhumabayev // USSR Computational Mathematics and Mathematical Physics. - 1989. - Vol. 29. - P. 34-46.

10 Джумабаев Д.С. Корректная разрешимость линейной многоточечной краевой задачи / Д.С. Джумабаев, А.Е. Иманчиев // Математический журнал. - 2005. - Т. 5. - No. 1(15). - С. 30-38.

11 Джумабаев Д.С. Критерий существования изолированного решения многоточечной краевой задачи для системы обыкновенных дифференциальных уравнений / Д.С. Джумабаев, А.Е. Иманчиев // Известия НАН РК. Серия физико-математическая. - 2010. - No. 3. - С. 117-121.

12 Асанова А.Т. О разрешимости семейства многоточечных краевых задач для системы дифференциальных уравнений и их приложения к нелокальным краевым задачам / А.Т. Асанова // Математический журнал. - 2013. - Т. 13. - No. 3. - С. 38-42. 
13 Assanova A.T. Multipoint problem for a system of hyperbolic equations with mixed derivative / A.T. Assanova // Journal of Mathematical Sciences. - 2016. - Vol. 212. - No. 3. - P. 213-233.

14 Асанова А.Т. Об однозначной разрешимости многоточечной краевой задачи для дифференциального уравнения третьего порядка / А.Т. Асанова, А.Е. Иманчиев // Известия НАН РК. Серия физико-математическая. - 2015. - No. 5 (303). - C. 124-132.

15 Assanova A.T. Solvability of multipoint-integral boundary value problem for a third-order differential equation and parametrization method / A.T. Assanova, A.E. Imanchiyev. In: Springer Proceedings in Mathematics \& Statistics. Functional Analysis in Interdisciplinary Applications. Ed.: T.Sh. Kalmenov, E.D. Nursultanov. M.V. Ruzhansky, M.A. Sadybekov. Astana, Kazakhstan, October 2017. — 2017. Vol. 216. - P. 113-122.

\author{
А.Т. Асанова, А.Е. Иманчиев
}

\title{
Үшінші ретті дифференциалдық теңдеу үшін көпнүктелі-интегралдық шеттік есептер әулетінің бірмәнді шешілімділігі туралы
}

\begin{abstract}
Мақалада коэффициенттері айнымалы үшінші ретті дифференциалдық теңдеу үшін көпнүктеліинтегралдық шеттік есептер әулеті қарастырылды. Бұл есептің жалғыз шешімінің бар болуы мәселелері мен оны табу жолдары зерттелді. Жаңа функциялар енгізу әдісі арқылы коэффициенттері айнымалы үшінші ретті дифференциалдық теңдеу үшін көпнүктелі-интегралдық шеттік есептер әулеті үш дифференциалдық теңдеуден тұратын жүйе үшін көпнүктелі-интегралдық шеттік есептер әулетіне келтіріледі. Нәтижесінде алынған көпнүктелі-интегралдық шеттік есептер әулетін шешу үшін параметрлеу әдісі қолданылды. Үш дифференциалдық теңдеуден тұратын жүйе үшін көпнүктелі-интегралдық шеттік есептер әулетінің жуық шешімдерін табу алгоритмдері ұсынылған және оның жинақтылығы дәлелденген. Үш дифференциалдық теңдеуден тұратын жүйе үшін көпнүктелі-интегралдық шеттік есептер әулетінің бірмәнді шешілімділігінің шарттары бастапқы берілімдер терминінде алынған. Нәтижелер сәйкесінше бастапқы коэффициенттері айнымалы үшінші ретті дифференциалдық теңдеу үшін көпнүктелі-интегралдық шеттік есептер әулеті үшін де тұжырымдалған.
\end{abstract}

Kiлm сөздер: көпнүктелі-интегралдық шеттік есеп, үшінші ретті дифференциалдық теңдеулер, параметр, көпнүктелі-интегралдық шеттік есептер әулеті, дифференциалдық теңдеулер жүйесі, алгоритм, бірмәнді шешімділік.

\author{
А.Т. Асанова, А.Е. Иманчиев
}

\section{Об однозначной разрешимости семейства многоточечно-интегральных краевых задач для дифференциального уравнения третьего порядка}

\begin{abstract}
В статье рассмотрено семейство многоточечно-интегральных краевых задач для дифференциального уравнения третьего порядка с переменными коэффициентами. Исследованы вопросы существования единственного решения рассматриваемой задачи и способы его построения. Методом введения новых функций семейство многоточечно-интегральных краевых задач для дифференциального уравнения третьего порядка с переменными коэффициентами сводится к семейству многоточечно-интегральных краевых задач для системы трех дифференциальных уравнений. Для решения полученного семейства многоточечно-интегральных краевых задач применяется метод параметризации. Предложены алгоритмы нахождения приближенного решения семейства многоточечно-интегральных краевых задач для системы трех дифференциальных уравнений, и доказана их сходимость. Получены условия однозначной разрешимости семейства многоточечно-интегральных краевых задач для системы трех
\end{abstract}


дифференциальных уравнений в терминах исходных данных. Результаты также сформулированы относительно исходного семейства многоточечно-интегральных краевых задач для дифференциального уравнения третьего порядка с переменными коэффициентами.

Ключевые слова: многоточечно-интегральная краевая задача, дифференциальное уравнение третьего порядка, параметр, семейство многоточечно-интегральных краевых задач, алгоритм, однозначная разрешимость

\section{References}

1 Krall, A.M. (1968). Differential operators and their adjoints under integral and multiple point boundary conditions. Journal of Differential Equations, Vol. 4, 327-336.

2 Brown, R.C., \& Krall, A.M. (1974). Ordinary differential operators under Stiltjes boundary conditions. Trans. Amer. Math. Soc., Vol. 198, 73-92.

3 Lan, C. (1975). Boundary value problems for second and third order differential equations. Journal of Differential Equations, Vol. 18, 258-274.

4 Samoilenko, A.M., \& Ronto, N.I. (1985). Chislenno-analiticheskie metody issledovaniia resheniia kraevykh zadach /Numerical-analytic methods of investigation of solutions of boundary value problems/. Kiev: Naukova dumka [in Russian].

5 Agarwal, R.P. (1987). Existence-uniqueness and iterative methods for third-order boundary value problems. Journal of Computational and Applied Mathematics, Vol. 17, 271-289.

6 Kiguradze, I.T. (1987). Kraevye zadachi dlia sistem obyknovennykh differentsialnykh uravnenii [Boundary value problems for systems of ordinary differential equations]. Itohi nauki i tekhniki. Sovremennye problemy matematiki. Novykh dostizheniia-Modern problems of mathematics. Advancement achievements, Vol. 30, 3-103. Moscow: Nauka.

7 Samoilenko, A.M., Laptinskii, V.N., \& Kenzhebayev, K.K. (1999). Konstruktivnye metody issledovaniia periodicheskikh i mnohotochechnykh kraevykh zadach [Constructive methods of investigation of periodic and multipoint boundary value problems]. Trudy Instituta matematiki NAN Ukrainy - Proceedings of Institute of mathematics of NAS of Ukraine, Vol. 29, 3-220. Kiev: Institute of mathematics of NAS of Ukraine [in Russian].

8 Xie, S., Li, P., Gao, Z., \& Wang, H. (2012). Applied Mathematics and Computation, 219, 2564-2573.

9 Dzhumabayev, D.S. (1989). Criteria for the unique solvability of a linear boundary-value problem for an ordinary differential equation. USSR Computational Mathematics and Mathematical Physics, Vol. 29, $34-46$.

10 Dzhumabaev, D.S., \& Imanchiev, A.E. (2005). Korrektnaia razreshimost lineinoi mnohotochechnoi kraevoi zadachi [Well-posedness of linear multi-point boundary value problem]. Matematicheskii zhurnal-Mathematical journal, Vol. 5, 30-38 [in Russian].

11 Dzhumabaev, D.S., \& Imanchiev, A.E. (2010). Kriterii sushchestvovaniia izolirovannoho resheniia mnohotochechnoi kraevoi zadachi dlia sistemy obyknovennykh differentsialnykh uravnenii [Criteria of existence izolated solution of multi-point boundary value problem for system of ordinary differential equations]. Izvestiia NAN RK. Seriia fiziko-matematicheskaia - Proceedings of NAS RK. Series of Physics and Mathematics, 3, 117-121 [in Russian].

12 Asanova, A.T. (2013). O razreshimosti semeistva mnohotochechnykh kraevykh zadach dlia sistemy differentsialnykh uravnenii i ikh prilozheniia k nelokalnym kraevym zadacham [About of the solvability of family multi-point boundary value problems for system of differential equations and their applications to nonlocal boundary value problems]. Matematicheskii zhurnal - Mathematical Journal, Vol. 13, No. 3, 38-42 [in Russian].

13 Asanova, A.T. (2016). Multipoint problem for a system of hyperbolic equations with mixed derivative. Journal of Mathematical Sciences, Vol. 212, 3, 213-233.

14 Assanova, A.T., \& Imanchiev, A.E. (2015). Ob odnoznachnoi razreshimosti mnohotochechnoi kraevoi zadachi dlia differentsialnoho uravneniia treteho poriadka [On the unique solvability of a multi-point boundary value problem for a third-order differential equation]. Izvestiia NAN RK. Seriia fiziko-matematicheskaia - News of the NAS of the RK. Phys.-Mathem ser., Vol. 5, 303, 124-132. 
15 Assanova, A.T., \& Imanchiev, A.E. (2017). Solvability of multipoint-integral boundary value problem for a third-order differential equation and parametrization method. In: Springer Proceedings in Mathematics \& Statistics. Functional Analysis in Interdisciplinary Applications. T.Sh.Kalmenov, E.D.Nursultanov. M.V.Ruzhansky, M.A.Sadybekov (Ed.). Astana, Kazakhstan, October 2017, Vol. 216, 113-122. 